\title{
Characterisation of related red-berried and white-berried grapevine cultivars
}

Conference Paper in Acta horticulturae · April 2013

DOI: $10.17660 /$ ActaHortic.2017.1157.19

CITATIONS

0

10 authors, including:

\section{Isaura Castro}

Universidade de Trás-os-Montes e Alto Douro 27 PUBLICATIONS 102 CITATIONS

SEE PROFILE

\section{Juan Pedro Martín}

Universidad Politécnica de Madrid

68 PUBLICATIONS 2,395 CITATIONS

SEE PROFILE

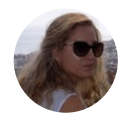

Vanessa Ferreira

Universidade de Trás-os-Montes e Alto Douro 16 PUBLICATIONS 37 CITATIONS

SEE PROFILE

\section{Jesús Ortiz}

Universidad Politécnica de Madrid

60 PUBLICATIONS 1,054 CITATIONS

SEE PROFILE 


\title{
Characterisation of related red-berried and white- berried grapevine cultivars
}

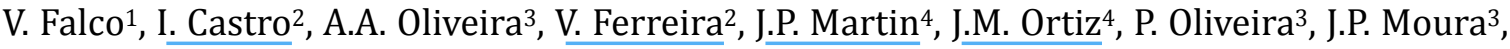 \\ N. Magalhães ${ }^{3}$ and O. Pinto-Carnide ${ }^{2}$ \\ ${ }^{1}$ Centro de Química, Vila Real (CQ-VR), University of Trás-os-Montes and Alto Douro, Vila Real, Portugal; \\ 2Institute for Biotechnology and Bioengineering, Centre of Genomics and Biotechnology (IBB/CGB), University of \\ Trás-os-Montes and Alto Douro, Vila Real, Portugal; ${ }^{3}$ Centre for the Research and Technology of Agro- \\ Environmental and Biological Sciences (CITAB), University of Trás-os-Montes and Alto Douro, Vila Real, Portugal; \\ ${ }^{4}$ Department of Plant Biology, E.T.S. Agronomics Engineering, Technical University of Madrid, Ciudad \\ Universitaria Madrid, Spain.
}

\begin{abstract}
Eight presumably related dark red-berried (dR), light red-berried (IR) and white-berried $(W)$ grapevine cultivars grown under similar environmental conditions were characterised on the basis of morphologic (phenotype) and molecular (genotype) parameters. The ampelographic characterisation was based on the main descriptors that correspond to the 'Primary descriptor priority list' suggested by the International Organisation of Vine and Wine (OIV). At the molecular level, the total genomic DNA of the cultivars was isolated from frozen grapevine leaves. Six microsatellite loci were used for characterisation of the grape cultivars: 'VVS2', 'VVMD5', 'VVMD7', 'VVMD27', 'VrZAG62', and 'VrZAG79'. This molecular characterisation allowed the confirmation, in seven of the eight studied cultivars, including dark red, light red and white-berried variants, of colour mutants with origin in three different varieties. 'Pinot Blanc' (W), 'Pinot Gris' (IR) and 'Pinot Noir' (dR) formed a group of colour mutants, and 'Malvasia Fina' (W) and 'Malvasis Fina Roxa' (IR) formed another group. 'Moscatel Galego Branco' (W) and 'Moscatel Galego Roxo' (IR) were confirmed as colour mutants, but their allelic profile was not related to that of 'Moscatel Galego Tinto' (dR).
\end{abstract}

Keywords: Vitis vinifera, grape berry colour, anthocyanins, microsatellite, SSR

\section{INTRODUCTION}

Grapevines (Vitis vinifera) are one of the most traditional and most important crops in Portugal where there are 343 different authorised wine production varieties, 169 of which are black, 152 white, and 22 grey. Occasionally the same variety is known under different names (synonymies) and sometimes the same name applies to different varieties (homonymies). In fact, several synonymies and homonymies were detected between these grape varieties by using different molecular markers, namely RAPDs, ISSRs and SSRs (PintoCarnide et al., 2003; Santiago et al., 2005; Martín et al., 2006; Castro et al., 2008, 2011; Martín et al., 2011), which are as the most indicated for biodiversity analysis and cultivar identification. However, no differences were observed between such varieties as 'Pinot Noir' and 'Pinot Blanc'.

There is no accurate information about exactly how many more cases exist of varieties like 'Pinot Noir' and 'Pinot Blanc', where the same variety suffered mutations that gave rise to different berry colouration. What distinguishes black from white varieties is the presence or absence of anthocyanins in several cell layers constituting the skin of the berry.

In grapevine, five very similar VvmybA genes were identified as putative regulators of anthocyanin synthesis in the red-berries cultivars (Kobayashi et al., 2002; Walker et al., 2007; Deluc et al., 2008). In the case of grape, extensive molecular physiology studies provide evidence that two adjacent transcription factors, $V v m y b A 1$ and $V v m y b A 2$, are able to induce the VvUFGT transcription needed for berry pigmentation (Ageorges et al., 2006; Walker et al., 2007). Somatic variation for berry skin colour has been associated with the 
presence of Gret1, a retrotransposon, in the promotor region of VvmybA1 (Kobayashi et al., 2004). The presence of this retrotransposon on white grapes obstructs VvmybA1 gene transcription and hinders anthocyanin biosynthesis activation. Another similar gene, VvmybA2, which is physically linked to VvmybA1, was also implicated in this trait (Walker et al., 2007). A final transcription factor, Vvmyb5b, was also shown to marginally induce the VvUFGT (Deluc et al., 2008).

In the present study three groups of supposedly related red-berried and white-berried grapevine cultivars were characterised in order to confirm if they are actually colour mutants. The studied grapevine cultivars were installed in an experimental vineyard at the University of Trás-os-Montes e Alto Douro (UTAD) campus in Vila Real, in the Baixo Corgo sub-region of the Demarcated Douro Region, northern Portugal.

The cultivars were characterised on the basis of morphologic parameters (phenotype) and molecular markers (genotype). The ampelographic characterisation was based on the 14 main descriptors that correspond to the 'Primary descriptor priority list' suggested by the International Organisation of Vine and Wine (OIV) in the Second Edition of the OIV Descriptors List for Grape Varieties and Vitis Species (OIV, 2009). For the molecular characterisation, six SSR (Simple Sequence Repeats) markers identified in the project GENRES \#081 were used as more suitable for the identification of grapevine cultivars ('VVS2', 'VVMD5', 'VVMD7', 'VVMD27', 'VrZAG62', and 'VrZAG79' and corresponding to OIV801-806 descriptors (OIV, 2009)).

\section{MATERIALS AND METHODS}

Vitis vinifera 'Pinot Blanc' (W), 'Pinot Gris' (lR), 'Pinot Noir' (dR), 'Malvasia Fina' (W), 'Malvasis Fina Roxa' (IR), 'Moscatel Galego Branco' (W), 'Moscatel Galego Roxo' (IR), and 'Moscatel Galego Tinto' (dR) (Table 1) were sampled from the same experimental vineyard located in Vila Real (Campus of University of Trás-os-Montes e Alto Douro, $41^{\circ} 17^{\prime} \mathrm{N}, 7^{\circ} 44^{\prime} \mathrm{W}$, $500 \mathrm{~m}$ above mean sea level, Baixo Corgo sub-region of the demarcated Douro Region, northern Portugal). All vines were grafted on 'SO4' and planted in a schistous soil. Plants were managed without irrigation and grown according to a commercial protocol, as applied in commercial farms.

Table 1. List of the studied accessions and allele sizes in base pairs at each of six microsatellite loci analysed.

\begin{tabular}{|c|c|c|c|c|c|c|c|c|c|c|c|c|}
\hline \multirow{3}{*}{ Cultivar } & \multicolumn{2}{|c|}{ VVS2 } & \multicolumn{2}{|c|}{ WMD5 } & \multicolumn{2}{|c|}{ VVMD7 } & \multicolumn{2}{|c|}{ VVMD27 } & \multicolumn{2}{|c|}{ VrZag62 } & \multicolumn{2}{|c|}{ VrZag79 } \\
\hline & Allele & Allele & Allele & Allele & Allele & Allele & Allele & Allele & Allele & Allele & Allele & Allele \\
\hline & 1 & 2 & 1 & 2 & 1 & 2 & 1 & 2 & 1 & 2 & 1 & 2 \\
\hline Malvasia Fina & 140 & 142 & 222 & 236 & 237 & 255 & 175 & 191 & 187 & 187 & 245 & 249 \\
\hline Malvasia Fina Roxa & 140 & 142 & 222 & 236 & 237 & 255 & 175 & 191 & 187 & 187 & 245 & 249 \\
\hline Moscatel Galego Branco & 130 & 130 & 224 & 232 & 231 & 247 & 175 & 191 & 185 & 195 & 249 & 253 \\
\hline el Galego Roxo & 130 & 130 & 224 & 232 & 231 & 247 & 175 & 191 & 185 & 195 & 249 & 253 \\
\hline Moscatel Galego Tinto & 130 & 148 & 222 & 224 & 237 & 247 & 175 & 185 & 185 & 187 & 249 & 253 \\
\hline Pinot Blanc & 134 & 148 & 224 & 234 & 237 & 241 & 181 & 185 & 187 & 193 & 237 & 243 \\
\hline Pinot Gris & 134 & 148 & 224 & 234 & 237 & 241 & 181 & 185 & 187 & 193 & 237 & 243 \\
\hline Pinot Noir & 134 & 148 & 224 & 234 & 237 & 241 & 181 & 185 & 187 & 193 & 237 & 243 \\
\hline
\end{tabular}

The ampelographic characterisation was based on the main descriptors that correspond to the 'Primary descriptor priority list' suggested by the Organisation Internationale de la Vigne et du Vin (Table 2) (OIV, 2009).

Young leaves from each accession were collected in the experimental vineyard. Leaves were kept at $-80^{\circ} \mathrm{C}$ and macerated in liquid nitrogen at the start of the extraction protocol. Genomic DNA was extracted using the DNeasy ${ }^{\circledR}$ Plant Mini Kit (QIAGEN) purification kit, according to the manufacturer's instructions. Extracted DNA was quantified by UV spectrophotometry (Nanodrop ${ }^{\circledR}$ ND-1000, Fisher Scientific) followed by quality check in a

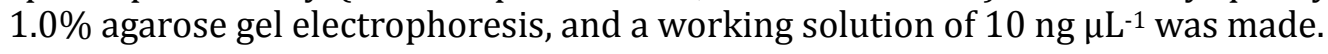


Table 2. Primary descriptor priority list suggested by the OIV (OIV, 2009).

\begin{tabular}{lc}
\hline Code & Descriptor \\
\hline OIV 001 & Young shoot: aperture of tip \\
OIV 004 & Young shoot: density of prostrate hairs on tip \\
OIV 016 & Shoot: number of consecutive tendrils \\
OIV 051 & Young leaf: colour of upper side of blade (4th leaf) \\
OIV 067 & Mature leaf: shape of blade \\
OIV 068 & Mature leaf: number of lobes \\
OIV 070 & Mature leaf: area of anthocyanin colouration of main veins on upper side of blade \\
OIV 076 & Mature leaf: shape of teeth \\
OIV 079 & Mature leaf: degree of opening/overlapping of petiole sinus \\
OIV $081-2$ & Mature leaf: petiole sinus base limited by veins \\
OIV 084 & Mature leaf: density of prostrate hairs between main veins on lower side of blade \\
OIV 087 & Mature leaf: density of erect hairs on main veins on lower side of blade \\
OIV 223 & Berry: shape \\
OIV 225 & Berry: colour of skin \\
\hline
\end{tabular}

A total of six microsatellite loci were amplified (Table 1), corresponding to the OIV core set: 'VVS2', 'VVMD5', 'VVMD7', 'VVMD27', 'VrZAG62', 'VrZAG79', that correspond to OIV801-806 descriptors (OIV, 2009). One primer of each pair was fluorescently labeled with 6-FAM (blue), TET (green) or HEX (yellow).

Each $20 \mu \mathrm{L}$ PCR reaction contained $2.5 \mathrm{mM}$ of dNTP, $25 \mathrm{mM}$ of $\mathrm{MgCl}_{2}, 10 \mathrm{ng}$ of template DNA, different concentrations of primers and $5 \mathrm{U} \mathrm{LL}^{-1}$ of Taq DNA polymerase in the manufacturer's buffer. PCR amplifications were performed in a T-100 TM Thermal Cycler (Bio-Rad, München, Germany), a basic thermocycler. The programme comprised an initial denaturation step $\left(95^{\circ} \mathrm{C} / 5 \mathrm{~min}\right)$, followed by 40 cycles of $94^{\circ} \mathrm{C} / 45 \mathrm{~s}, 50^{\circ} \mathrm{C} / 60 \mathrm{~s}$ and $72^{\circ} \mathrm{C} / 90$ s.

Two multiplex PCRs were carried out with the OIV SSR core set, the first one involving 'VVS2', 'VVMD5' and 'VVMD7' (set A), and the second 'VVMD27', 'VrZAG62' and 'VrZAG79' (set $B)$.

The set $A$ multiplex reactions contained $0.2 \mu \mathrm{M}$ of each VVS2 primer, $0.5 \mu \mathrm{M}$ of each VVMD5 primer, and $0.25 \mu \mathrm{M}$ of the VVMD7 primers; and the set $B$ reactions contained $0.5 \mu \mathrm{M}$ of each VVMD27 and VrZAG79 primers, and $0.1 \mu \mathrm{M}$ of each VrZAG62 primer.

The amplicons were separated in a $3 \%(\mathrm{w} / \mathrm{v})$ agarose gel electrophoresis in TBE buffer, for $2 \mathrm{~h}$ at a constant voltage of $120 \mathrm{~V}$, followed by ethidium bromide staining and by capillary electrophoresis (ABI PRISM model 310, PE Applied Biosystems, CA, USA). GENESCAN-350 TAMRA (PE Applied Biosystems, CA, USA.) was included as an internal sizing standard and labeled products were analysed and sized using Peak Scanner V1.0 software (PE Applied Biosystems, CA, USA).

\section{RESULTS AND DISCUSSION}

Analysing the SSR loci amplified using multiplex PCR, it was possible to identify seven true berry colour mutant cultivars, out of the eight analysed, belonging to three distinct varieties (Table 1). The cultivars of each variety identified as true berry colour mutants showed the same SSR pattern, i.e., the same alleles in all SSR loci, being distinguished by the colour of the berry skin. Thus, despite the fact that these cultivars vary in relation to the colour of the berry, they were considered true berry colour mutant cultivars with the same SSR profile and origin in one single variety. This was the case of the groups Pinot ('P. Blanc', 'P. Gris' and 'P. Noir') and Malvasia ('Malvasia Fina' and 'Malvasia Fina Roxo'). However, the three 'Moscatel Galego' cultivars revealed two different SSR profiles, one of the mutant cultivars 'Moscatel Galego Branco' and 'Moscatel Galego Roxo' and another of 'Moscatel Galego Tinto' - the last one showing a different genotype.

Apart from berry colour, the cultivars with the same SSR profile presented similar ampelographic characteristics (Figure 1). 

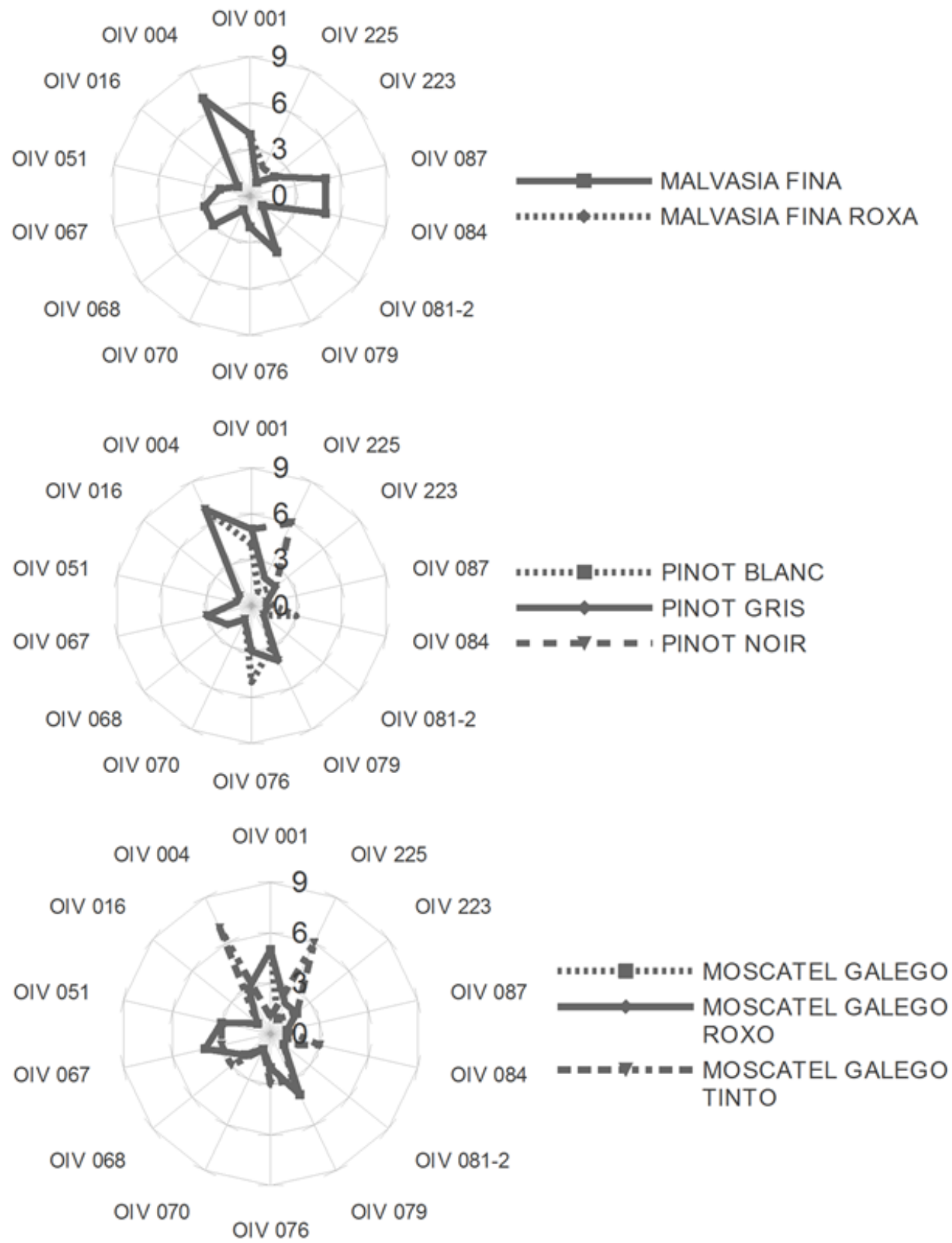

Figure 1. Ampelographic characterisation based on the main descriptors that correspond to the 'Primary descriptor priority list' suggested by the OIV (see Table 2).

\section{CONCLUSIONS}

Through the amplification of the six OIV SSR core set and the 14 OIV primary descriptors, this study allowed the identification of three varieties that by mutation originated seven cultivars, with berry colour skin somatic variants.

In the future, varieties and respective cultivars with different berry skin will be analysed using other molecular marker techniques to assess cultivar specific markers, eventually linked to the berry skin colour.

\section{ACKNOWLEDGMENTS}

Financial support from Project FCT PTDC/AGR-PRO/120264/2010. 


\section{Literature cited}

Ageorges, A., Fernandez, L., Vialet, S., Merdinoglu, D., Terrier, N., and Romieu, C. (2006). Four specific isogenes of the anthocyanin metabolic pathway are systematically co-expressed with the red colour of grape berries. Plant Sci. 170 (2), 372-383 http://dx.doi.org/10.1016/j.plantsci.2005.09.007.

Castro, I., Martin, J.P., Ortiz, J.M., Garrido, J., and Pinto-Carnide, O. (2008). Variabilidad genómica en cultivares de Vitis vinifera de las regiones Portuguesas "Douro" y "Vinhos Verdes" determinada mediante marcadores de tipo microsatélite. Paper presented at: XXXI World Congress of Vine and Wine (Verona, Italy).

Castro, I., Martín, J.P., Ortiz, J.M., and Pinto-Carnide, O. (2011). Varietal discrimination and genetic relationships of Vitis vinifera L. cultivars from two major Controlled Appellation (DOC) regions in Portugal. Sci. Hortic. (Amsterdam) 127 (4), 507-514 http://dx.doi.org/10.1016/j.scienta.2010.11.018.

Deluc, L., Bogs, J., Walker, A.R., Ferrier, T., Decendit, A., Merillon, J.M., Robinson, S.P., and Barrieu, F. (2008). The transcription factor VvMYB5b contributes to the regulation of anthocyanin and proanthocyanidin biosynthesis in developing grape berries. Plant Physiol. 147 (4), 2041-2053. PubMed http://dx.doi.org/10.1104/pp.108.118919

Kobayashi, S., Ishimaru, M., Hiraoka, K., and Honda, C. (2002). Myb-related genes of the Kyoho grape (Vitis labruscana) regulate anthocyanin biosynthesis. Planta 215 (6), 924-933. PubMed http://dx.doi.org/10.1007/ s00425-002-0830-5

Kobayashi, S., Goto-Yamamoto, N., and Hirochika, H. (2004). Retrotransposon-induced mutations in grape skin color. Science 304 (5673), 982. PubMed http://dx.doi.org/10.1126/science.1095011

Martín, J.P., Santiago, J.L., Pinto-Carnide, O., Leal, F., Martínez, M.C., and Ortiz, J.M. (2006). Determination of relationships among autochthonous grapevine varieties (Vitis vinifera L.) in the Northwest of the Iberian Peninsula by using microsatellite markers. Genet. Resour. Crop Evol. 53 (6), 1255-1261 http://dx.doi.org/ 10.1007/s10722-005-5679-6.

Martín, J.P., Arranz, C., Castro, I., Yuste, J., Rubio, J.A., Pinto-Carnide, O., and Ortiz, J.M. (2011). Prospection and identification of grapevine varieties cultivated in north Portugal and northwest Spain. Vitis 50, 29-33.

OIV (Organisation Internationale de la Vigne et du Vin). (2009). 2 ${ }^{\text {nde }}$ Edition de la Liste des Descripteurs OIV pour les Varietes et Especes de Vitis (Paris: OIV).

Pinto-Carnide, O., Martín, J.P., Leal, F., Castro, I., Guedes-Pinto, H., and Ortiz, J.M. (2003). Characterization of grapevine (Vitis vinifera L.) cultivars from northern Portugal using RAPD and microsatellite markers. Vitis 42, 2325.

Santiago, J.L., Boso, S., Martínez, M.C., Pinto-Carnide, O., and Ortiz, J.M. (2005). Ampelographic comparison of grape cultivars (Vitis vinifera L.) grown in northwestern Spain and northern Portugal. Am. J. Enol. Vitic. 56, 287290.

Walker, A.R., Lee, E., Bogs, J., McDavid, D.A.J., Thomas, M.R., and Robinson, S.P. (2007). White grapes arose through the mutation of two similar and adjacent regulatory genes. Plant J. 49 (5), 772-785. PubMed http://dx.doi.org/ 10.1111/j.1365-313X.2006.02997.x 
